\title{
Role of NGOs in Implementation of CSR Activities in India
}

\author{
Bindhu D. ${ }^{1 *} \&$ Niyaz $^{2}$ \\ ${ }^{1}$ Research Scholar, College of Management \& Commerce, \\ Srinivas University, Mangalore, India. \\ OrcidID:0000-0003-3714-3331; Email: bindhuranjith11@ gmail.com \\ ${ }^{2}$ Assistant Professor, College of Management \& Commerce, \\ Srinivas University, Mangalore, India. \\ OrcidID: 0000-0003-4568-1658; Email: niyaz0191@gmail.com
}

Area/Section: Business Management.

Type of the Paper: Review based Exploratory Research.

Type of Review: Peer Reviewed as per $|\mathrm{C}| \mathrm{O}|\mathrm{P}| \mathrm{E} \mid$ guidance.

Indexed in: OpenAIRE.

DOI: https://doi.org/10.5281/zenodo.5519023

Google Scholar Citation: IJMTS

\section{How to Cite this Paper:}

Bindhu, D., \& Niyaz, (2021). Role of NGOs in Implementation of CSR Activities in India. International Journal of Management, Technology, and Social Sciences (IJMTS), 6(2), 100-107. DOI: https://doi.org/10.5281/zenodo.5519023

International Journal of Management, Technology, and Social Sciences (IJMTS)

A Refereed International Journal of Srinivas University, India.

CrossRef DOI: https://doi.org/10.47992/IJMTS.2581.6012.0156

(C) With Author.

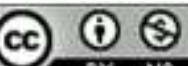

This work is licensed under a Creative Commons Attribution-Non-Commercial 4.0 International License subject to proper citation to the publication source of the work.

Disclaimer: The scholarly papers as reviewed and published by the Srinivas Publications (S.P.), India are the views and opinions of their respective authors and are not the views or opinions of the SP. The SP disclaims of any harm or loss caused due to the published content to any party. 


\title{
Role of NGOs in Implementation of CSR Activities in India
}

\author{
Bindhu D. ${ }^{1 *} \&$ Niyaz $^{2}$ \\ ${ }^{1}$ Research Scholar, College of Management \& Commerce, \\ Srinivas University, Mangalore, India. \\ OrcidID:0000-0003-3714-3331; Email: bindhuranjith11@gmail.com \\ ${ }^{2}$ Assistant Professor, College of Management \& Commerce, \\ Srinivas University, Mangalore, India. \\ OrcidID: 0000-0003-4568-1658; Email: niyaz0191@ gmail.com
}

\begin{abstract}
Purpose: Corporate social responsibility is becoming a necessary component of doing business. India is the first country to establish a minimum wage for CSR initiatives aimed at improving the future. The Indian government has implemented new CSR criteria that require businesses to invest $2 \%$ of their net profit in such projects. CSR enables businesses to contribute to the betterment of society, the environment, and nature to achieve this goal. NGO's play an important role because they manage various financial assistance programs and assist businesses in achieving various goals. This study is mainly focused to know the contribution of CSR made the business organization toward inclusive growth and the reasons beyond the implementation on CSR by business organization.

Methodology: Business organisations' contributions to inclusive growth through corporate social responsibility are examined in this study, as are the reasons for CSR's adoption by businesses. A case study is used to examine the role of non-profit organisations in the implementation of CSR activities. This study focuses on the role of non-governmental organisations in implementing CSR activities that benefit society by creating a systematic framework.
\end{abstract}

Findings: The paper finds that majority of the organizations are conscious of the concept of Corporate Responsibility, which means most of the organizations they are responsible for society.

Practical Implications: This study implies that CSR is based on the profit and need of society. Building strong public-private partnerships and working closely with nongovernmental organizations (NGOs) as implementation partners is accomplished through company's collaborative methods by organizations and various NGOs at the ground level are needed to develop which is beyond micro-credit to increase women's endowments and improve their trade outcomes vis-à-vis the family markets state and community.

Originality/Value: These findings have been made based on available secondary data and have identified the role played by non-governmental organisations in the implementation of CSR activities, as well as how their priorities and focus shifted towards developing society. This paper also outlines the evolution and advancements of CSR activities

Paper Type: Conceptual Research.

Keywords: Corporate Social Responsibility, Non-Governmental Organizations, Society, Corporations.

\section{INTRODUCTION :}

Since the 1990s, corporate social responsibility (CSR) activities have become a common way for most Indian businesses to contribute to the country's inclusive development. Companies are also actively investing in CSR campaigns by allocating 2-5 percent of their net profits to the cause. Companies are also required to donate two percent of their net profit to charity under the new Companies Bill. Aside from the private sector, the government is ensuring that public-sector businesses invest in CSR initiatives as well. In India, corporate social responsibility has gone through many stages. Some 
businesses have demonstrated their ability to create a good impact on society and improvement in the superiority of life. To attain a sustainable and long-term solution to India's social challenges, all corporations should aim to enhance the current social situation. Partnerships between corporations, nongovernmental organisations, and the government should be fostered so that their talents, For instance, India's socioeconomic growth can be enhanced by combining considerations such as expertise and strategic thinking with manpower and other resources. CSR (Corporate Social Responsibility) is becoming a more significant part of a business's overall strategy. A company's voluntary compliance with its social and environmental responsibilities is referred to as corporate social responsibility. Businesses choose to actively contribute to a healthier community and a safer world under this philosophy. Social and environmental responsibility is a term used by corporations to describe their willingness to integrate social and environmental concerns into their business processes and relationships with stakeholders. Business practises and social investments are what define it. According to the sustainability principle, businesses should make decisions based not only on profits and dividends, but also on immediate and long-term social and environmental consequences. CSR refers to an organization's responsibility for the impact of its actions and operations on society, the environment, and its own financial well-being, sometimes known as the TRIPLE BOTTOM LINE of people, planet, and profit. Charitable impulses in family enterprises evolve into long-term concerted philanthropic activities, resulting in the formation of corporate social responsibility. CSR involves every department and employee, and each one has a distinct responsibility to perform. CSR is also a company-wide initiative that includes production, distribution, and even marketing. The Companies Act of 2013 has given Corporate Sustainability in India a new lease on life over the last four years. In order to comply with the law, companies with a net worth of Rs 500 crores or more, a revenue of Rs 1,000 crores or more, and a net profit of Rs 5 crores or more are required to make a minimum investment in corporate social responsibility. India is the first country to require a certain level of CSR spending. In order to promote a brighter future, the Indian government has introduced new CSR criteria that compel businesses to invest 2 percent of their net profit in social development [1].

\section{RESEARCH OBJECTIVES :}

These studies are primarily concerned with corporate sustainability in India as well as its emerging patterns. They also look at companies' roles in fostering an environment where the public can benefit from such collaborations between corporations and non-governmental organisations.

\section{RESEARCH METHODOLOGY :}

The study is a descriptive and exploratory one in terms of its purpose and methodology. The information is gathered from a variety of secondary sources for review. Company annual reports are used to compile the data while non-profit organisations websites are used to compile the numbers. The secondary sources include published literature from various scholarly journals searched through Google scholar using keywords.

\section{EVOLUTION AND ADVANCEMENT OF CSR IN INDIA :}

India's culture has long been immersed with the idea of corporate social responsibility. Even before CSR became a hot topic, companies like TATA and BIRLA had been trying to integrate social good into their operations for decades. Since Jamshedji Tata founded the company in the 1860s, the Tata Group has shown very little interest in community welfare. Thus, Tata Sons, the promoter firm for the Tata Group that has created numerous national institutions in science and technology, medical research and social studies, and the performing arts, is sponsored by approximately two philanthropic trusts. Dr. Kurien is the leader of Amul. By working with dairy farmers at the grass-roots level, Operation Flood had set the ground for inclusive growth, improving people's lives, enhancing income, empowering women, and reaping business benefits. Since its founding in 1964, Indian Oil has made corporate social responsibility (CSR) a pillar of its success. "...to significantly boost the community's quality of life while safeguarding conservation balance and inheritance through a strong environmental conscience," the Corporation's ambitions in this core performance area declare. Before it became a part of the corporate lexicon, the Birla Group's value systems were already textured with Corporate. Social responsibility is an important concept. G.D. Birla, the company's founder, advocated trusteeship management as early as the 1940s. As a result, all of our stakeholders are assured that the money we create and sustain is kept in a trust 
fund. It's important to remember that corporate social responsibility requires us to give back a portion of our profits to organisations that benefit society. CSR has become increasingly important in India as businesses see the worth of investing in it to get benefits such as higher shareholder value, this includes strategic branding, operational performance, improved access to resources, as well as improved access to human and intellectual capital, as well as lower business risk for years, corporate social responsibility (CSR) has been used to integrate business and government activities in order to achieve common goals [2].

\section{NON-GOVERNMENTAL ORGANIZATIONS (NGOs) :}

As the name implies, a non-governmental entity is not affiliated with the government and is not a forprofit company. Founded by one person, it can be backed by governments, corporations, or private individuals, depending on the circumstances. In different parts of the world, non-governmental organisations (NGOs) engage in a wide range of activities. It's possible that some of them are philanthropic, registered as tax-exempt entities, or affiliated with interest groups. NGOs work to improve society and the environment through providing education to children, empowering women, planting trees, reducing hunger and poverty, and so forth. Corporates are banding together in their efforts to better society through their CSR services. It's possible that the businesses are making a name for themselves in the communities where they're based, and that they're receiving support from some members of the community. NGO jobs is increasing, and corporations are partnering with NGOs to carry out their CSR initiatives. Furthermore, several positions are generated outside of nongovernmental organisations. This paper discusses some of the NGO CSR services that have been implemented by organisations [3].

\section{A TREND FROM CHARITY TO RESPONSIBILITY IN CSR :}

Until the 1990s, the concept of philanthropy dominated corporate social responsibility (CSR). Instead of investing in socially responsible ventures, companies that view CSR as a philanthropic act are more likely to make one-time financial gifts. Moreover, companies never considered stakeholders when implementing such programmes, reducing the quality and effectiveness of their CSR efforts. However, in recent years, social responsibility has changed. Giving as an obligation or benevolent act seems to have given way to giving as a policy or liability. CSR in India is moving away from charity and reliance toward empowerment and partnership according to a review of case studies and CSR work done by Indian businesses [4].

\subsection{In Indian NGOs, CSR Initiatives are Making a Difference:}

The business sector has only just begun to recognise its power to assist in the settlement of the difficulties that CSR addresses. The commercial sector has accepted social responsibility and backed the government's commitment to expanding economic possibilities for the underprivileged.

\section{CSR ACTIVITIES THROUGH NGOs:}

\section{(1) Agastya International Foundation:}

The Agastya International Foundation has been a revolutionary educational organisation in India since 1999, vigorously extending hands-on learning to impoverished rural and urban children and teachers. Agastya's vision and mission are carried out in rural India by mobile labs the organization's innovation lab is located on a.172-acre campus near to Kuppam, Andhra Pradesh, and is visited by more than 500 students every day, whose interest is piqued by Agastya's hands-on teaching methods. Every year, Agastya's innovative pedagogy reaches over 1.5 million children and 200,000 teachers through 130 mobile labs in over a dozen Indian states and 50 science centres in eighteen states. Entrepreneurs, scientists, academics, philanthropists, and teachers are among Agastya's advisors and representatives. As a result of our continued efforts, Agastya has positively affected six million children and 200,000 teachers. These figures are increasing by the day [5].

Table 1: Agastya International Foundation

\begin{tabular}{|c|c|}
\hline Name & Agastya International Foundation \\
\hline Types of Registration & Non-Government Organization \\
\hline
\end{tabular}




\begin{tabular}{|c|c|}
\hline Founded & 1999 \\
\hline Founder & Ramji Raghavan \\
\hline Area of Work & We at All Over India work on education. \\
\hline Address & $\begin{array}{c}\text { 101 Varsav Plaza, 12 Jaymahal Main Road, Bangalore }-560046, \\
\text { INDIA }\end{array}$ \\
\hline Contact Details & info@agastya.org \\
\hline
\end{tabular}

Source: www.ngofeed.com

\section{(2) Inchara Foundation:}

Inchara Foundation, a registered non-profit organisation, focuses on girls (children and adolescents) who have been sexually abused, assisting them with the recovery process, trauma counselling, and selfdependency capacity growth programmes. We've developed a number of programmes targeted at preventing and protecting children from sexual violence, spanning from preventive to intervention. Inchara Home is focusing on Rehabilitation \& Restoration while Project Angel is focusing on prevention. Pocso Support Group is being formed to assist parents and family members of child sexual abuse victims. We are building a healthy environment for children both within and outside of schools through the Model Safe School Initiative [5].

Table 2: Inchara Foundation

\begin{tabular}{|c|c|}
\hline Name & Inchara Foundation \\
\hline Types of Registration & Non-Profit Organization \\
\hline Founded & 2008 \\
\hline Founder & Preetham Rodrigues \\
\hline Area of Work & $\begin{array}{c}\text { We work on girls (children \& adolescents) who are victims of } \\
\text { sexual abuse, helping them with the rehabilitation process, trauma } \\
\text { counselling and skill development activities for self-dependency. }\end{array}$ \\
\hline Official Website & www.incharafoundation.org \\
\hline Address & $15-17 / 871$ 2nd Cross, Kadri Shivabhag Mangalore -575002 \\
\hline Contact Details & info@incharafoundation.in \\
\hline S
\end{tabular}

Source: $\underline{w w w . n g o f e e d . c o m}$

(3) Rehabilitative Assistance for People in Distress:

Since 2001, the NGO Rehabilitative Assistance for People in Distress (RAPID) has been serving women in Dharwad. We put together rehabilitative services for single women, single mothers, and women in need by providing counselling, education, skill growth, and job opportunities [5].

Table 3: Rehabilitative Assistance for People in Distress

\begin{tabular}{|c|c|}
\hline Name & Rehabilitative Assistance for People in Distress \\
\hline Types of Registration & Non-Government Organization \\
\hline Founded & Mr. Vijay Kulkarni, Chairman \\
\hline Founder & Reohabilitative Assistance for People in Distress \\
\hline Area of Work & $\begin{array}{c}\text { We assemble rehabilitative care for Single Women, Single } \\
\text { Mothers and Women in distress by creating social and economic } \\
\text { opportunities through counselling, education, skill development } \\
\text { and employment. }\end{array}$ \\
\hline
\end{tabular}




\begin{tabular}{|c|c|}
\hline Types of Registration & Non-Government Organization \\
\hline
\end{tabular}

Source: www.ngofeed.com

(4) Guardians of Dreams:

Guardians of Dreams is a new non-profit organisation that works with children raised in orphanages, open shelters, observation homes, and adoption centres who need care and safety. Sur un total de 2 crore orphaned children, each urban district has approximately 5000 orphaned children living in CCIs. It has reached out to over 6500 children in Bengaluru, Chennai, and Ernakulam through its current initiatives, and has created a network of 250+ Child Care Initiatives (CCI) [5].

Table 4: Guardians of Dreams

\begin{tabular}{|c|c|}
\hline Name & Guardians of Dreams \\
\hline Types of Registration & Non-Profit Organization \\
\hline Founded & 2015 \\
\hline Founder & Gloria Benny \\
\hline Area of Work & $\begin{array}{l}\text { We work on works with children in need of care and protection } \\
\text { who grow up in Child Care Institutions (CCIs) like orphanages, } \\
\text { open shelters, observation homes, adoption centres etc. }\end{array}$ \\
\hline Official Website & www.godreams.org \\
\hline Address & $\begin{array}{c}\text { No. 8, New Friend's Colony, 11th Main, 8th Cross, ST Bed Layout, } \\
\text { Koramangala, Bangalore }-560047\end{array}$ \\
\hline Contact Details & contact@godreams.org \\
\hline
\end{tabular}

Source: www.ngofeed.com

\subsection{Challenges of CSR :}

Considering that more than 900 million people have access to a cell phone, but only 600 million people (36 percent) have access to a clean toilet, CSR could be a path to social improvement The top 100 companies in India currently spend about 0.6 billion dollars a year on CSR. According to the new guidelines, around 6,000 Indian companies will be forced into CSR projects, with many participating for the first time in their lives. In India, CSR expenditure is expected to reach 1.8 billion each year, according to projections. It's difficult to pick a reputable NGO out of a sea of them. However, in addition to providing a comprehensive evaluation of NGOs, NGO portals group NGOs according to their field of work (such as education, sanitation, women's welfare, water, livelihood, and children). People with good intentions but lacking the necessary skills to establish a non-profit organisation in India set up the vast majority of NGOs, with funding coming from donations and personal sources. Several rely on parttime volunteers and have a small staff of paid workers. India currently has over 100,000 CSR-ready NGOs with an annual compressive strength of approximately 20 lakhs. In addition, well-known corporations such as Infosys, Aditya Birla Group, Reddys, and Wipro have their own CSR programmes. Another fascinating aspect is that huge corporations, such as the Aditya Birla Group, engage with likeminded bilateral and unilateral agencies to share ideas, learn from one another's experiences, and reduce complexity of CSR initiatives. NGOs can make a difference by acting as a catalyst for corporate resources to be pooled, avoiding duplication of effort and dilution of influence. One of the major difficulties is the lack of transparency

\section{FINDINGS :}

1. According to researchers, almost all of the company's employees have a clear understanding of CSR activities as a result, CSR acts as a bridge between the community and an organization's recruitment and retention strategy, as well as an important tool for environmental preservation According to the findings, almost all officials are aware of the precise position of CSR activities in the corporate world.

2. As a rule, major radio organisations are involved in CSR in areas such as primary education promotion, women and children' welfare, rural development, and public health. Conclusion: CSR activities in India are on the rise, and they are playing a significant role in areas where they were previously lacking.

3. For their CSR activities, organisations have used a variety of methods. To implement CSR agreements, the majority of organisations are collaborating with government agencies, rather than hiring 
separate qualified employees. To create charitable trusts, some organisations work with NGOs and government agencies. This route was chosen in order to save money on the cost of maintaining a separate CSR for workers' training and other costs.

4. There is no doubt that every organisation has a specific goal in mind when it comes to CSR. Nowadays, the primary goal of CSR is to increase a company's overall contribution to society, all the while enjoying government tax breaks. There's no doubt that corporate social responsibility (CSR) as a whole has become more relevant due to a greater awareness of corporate social responsibility and ethical and environmental concerns.

5. It was found that companies benefit from CSR initiatives. Therefore, CSR is defined as an organisational strategy that promotes long-term growth and progress by providing social, economic and environmental benefits to enterprises as well the wider community

6. Participant engagement has proven difficult even when it comes to implementing CSR initiatives. It's the lack of community support that's been the most difficult for this organisation to overcome. Also, finding workers who are qualified and willing to participate in CSR activities can be a challenge. There are no specific guidelines or instructions available for corporate social responsibility (CSR). A positive correlation exists between the size of CSR programmes and the size of corporations and company announcements.

7. We found that Indian organisations' efforts to engage in CSR lacked specific guidance on investment parameters, impact majoring requirements, and CSR-related areas to be protected.

\section{SUGGESTIONS :}

1. For CSR projects to be successful, raising public awareness about CSR is essential. CSR projects are more likely to be successful if the public is made aware of them.

2. Even when it comes to implementing CSR programmes, involving stakeholders has proven difficult. In this organisation, the biggest obstacle is the lack of community support or a lack of response from the public. In addition, it's difficult to find workers who are qualified and suitable for CSR activities. No specific instructions or policies govern CSR activities. While CSR activities vary in size between large and small corporations and companies, large corporations have more CSR activities than smaller corporations.

3. CSR activities are closely monitored and closely collaborated with implementation partners, including NGOs, to ensure that programmes achieve their goals.

\section{CONCLUSION :}

As far as ensuring a company's long-term viability, CSR in India has come a long way. There is an effective connection between industry, social inclusion, and environmental sustainability. Initiatives by corporations have shown their ability to have a positive impact on society and improve quality of life, from responsive practises to environmental programmes. While CSR in India is still in its infancy, it has made significant strides in terms of the company's long-term viability as well as ensuring impartiality to all stakeholders Industries, social inclusion, and environmental sustainability have a very strong connection that has been very successful. Many corporate initiatives, from responsive practises to environmental programmes, have demonstrated their ability to have a positive impact on society and to improve quality of life.

\section{REFERENCES :}

[1] Swarnalathan, R., \& Anuradha, R. K. (2017). The Role of NGOs in achieving Corporate Social Responsibility. International Journal of Advanced Science and Research, 2(2), 27-30.

[2] Shan, S. (2017). Corporate-NGO Partnership. Capacity Building for Successful CSR Programme. International Journal of Technical Research \& Science, 2(4), 197-205.

[3] David, W., Praveen, R.D., \& Vijayalakshmi, R. (2014). Role of NGOs in CSR. International Research Journal of Business and Management, 7(12), 8-14.

[4] Sarla, P.D., Khandare, D.M., \& Jadhav, B. (2016). CSR: The Role of Non-Profit Organization and voluntary groups for Creation of Better Environment in developing countries. IOSR Journal of Business and Management (IOSR-JBM), 18(2), 96-99. 
[5] Hani, (2021). Top NGOs in Karnataka: Who is providing a better society? Retrieved from https://ngofeed.com/top-ngo-in-karnataka/ 